\title{
CONCEPTIONS OF LANDSCAPE-ECOLOGICAL RELEVANCE EMERGED IN THE CZECH BOTANY DURING THE SECOND HALF OF TWENTIETH CENTURY
}

\author{
PAVEL KOVÁŘ \\ Department of Botany, Faculty of Science, Charles University, Benátská 2, 12801 Praha 2, \\ e-mail: pavel.kovar@natur.cuni.cz
}

Received: $22^{\text {nd }}$ June 2015 , Accepted: $30^{\text {th }}$ July 2015

\begin{abstract}
This paper summarizes those substantial theoretical concepts or methods for applications within interdisciplinary or practical uses published by Czech autors (geobotanists = ecological botanists, plant ecologists and ecophysiologists) during the second half of the $20^{\text {th }}$ century, that were internationally cited. All selected thematical clusters are of landscape-ecological relevance through various contexts. Examples include the concepts of (potential) reconstructed vegetation in maps (R. Neuhäusl, Z. Neuhäuslová), linear vegetation features (corridors in landscape) and deductive classification of vegetation (K. Kopecký), analysis of soil seed bank (Z. Kropáč), dependency of macrophyte plant stands on ecodynamics (S. Hejný), dynamic periodicity in segetal vegetation (Z. Kropáč, E. Hadač, S. Hejný), anemo-orographic system explaining species richness in mountain regions (J. Jeník), productivity in grassland ecosystems (M. Rychnovská, J. Květ), elementary landscape units based on homogenity and potential vegetation (E. Hadač), landscape dispensation phenomena (V. Ložek), afforestation of coastal sandy dunes - the Netherlands, and polluted areas - the Czech Republic (J. Fanta), invasive plants and invasions into landscapes (M. Rejmánek).
\end{abstract}

Key words: conceptions within Czech botany, relevance to landscape level, mapping of potential vegetation, structure and dynamics in landscapes, corridors, deductive classification of vegetation, soil seed bank, productivity and ecophysiology of grasslands, agroecocycles and segetal vegetation, dynamics of wetlands, anemo-orographic systems, disturbance, diversity of plants, invasive plants and invasions.

\section{INTRODUCTION}

Vegetation forms a stabilising and at the same time dynamic interactive boundary between the atmosphere and the Earth's surface (the so called "green mantle"). The architecture and the metabolism of vegetation cover are considered to be the defining moments in the operation of ecosystems forming landscapes on the scales of large territories. That is the reason why the inventions and conceptual attitudes of botanists, regardless whether vegetation ecologists, ecophysiologists, or representatives of other subdisciplines of botany, always to some extent influenced the directions of work with landscape. Approximately the last 50 years of the last century brought the evolution of a strong generation of scientists - 
unfortunately with limited application within the wide international forum influenced largely by the restrictions of contacts with the western world caused by the former communist regime in Czechoslovakia. Despite that, at least some scientists reached abroad, attended scientific conferences or published in international journals with reasonable citing response.

In this attempt to present selected information on the important contributions of the post-war botanists towards the understanding of the ecosystem or landscape level of nature, I will first list several proofs that the knowledge of the need to work rationaly with the landscape, was already apparent in the previous generations. Professor Jaromír Klika, one of the first founders of the Czech phytocoenology, wrote in his publication "Plánujeme $\mathrm{s}$ př́rodou" (Brázda, Prague, 1948): (Planning with Nature). A biologist must be an expert botanist with understanding of not only vegetation but also ecology (of woody plants, pastures, etc.). He will be often forced to work along with a zoologist... " J. Klika highlights the cooperation of various experts. In a different section of his work on the increased care for montane woodlands (where it is necessary to prevent deforestation), dwarf mountain pine growth (where it is necessary to prevent burning) or peat bogs (where it is necessary to protect water regime), he references another Moravian naturalists and philosopher V. Úlehla (Napojme prameny, Praha 1947): "Every non-natural act of violence results in....hidden or other resistance and will be punished. And; therefore, in this case, the nature itself, obviously as well as in a hidden way, protested against the dictate. "The conclusion is: it is crucial for farmers and foresters to agree certain rules with biologists. J. Klika refers in the conclusion to "Souhrn zásad biologického plánování" (Summary of rules for biological planning) by R. Mikyška (1948) - later the first director of the so called Geobotanical Laboratory, Czechoslovak Academy of Sciences, in Prühonice, the predecessor of the Institute of Botany CSAS and/or Academy of Sciences of the Czech Republic (AV CR). These rules can be divided to Landscape Analysis (10 points) and Landscaspe Regeneration (12 points).

\section{FOUNDATIONS FOR THE WORK WITH LANDSCAPE}

Let's take a step to the period beyond the first half of the 20th century. The introduction brought our attention to the fact that the general awareness of the necessity to work rationally and sensitively in cooperation with landscape and in landscape has existed across generations and in its basics remains unchanged today. The understanding of the kind of data needed and the way of their interpretation, allowing for further basic as well as applied research or practice, developed gradually. This is supported for example by a relatively concisely formulated paper of a geobotanists and employee of Terplan, J. Štěpán from 1976: Prognóza krajinoekologických podmínek fytogeografických okresů ČSR (Preslia, 48). (Prognosis of landscape ecological conditions of phytogeographic regions of the Czech Socialist Republic). He describes the aims of his paper (page 166): "It is an attempt for a perspective view on the development of the landscape and the conditions of the development of the vegetation cover in particular, because these will be affected by the development of the population of our country, the development of urbanisation and other factors... ". There is an estimation included in the conclusion of the paper, formed on the regional planning system basis, stating where is it necessary to intensify the collection of biological data, where to anticipate increased nature conservation within the legislation and where it is crucial to reassess the standing landscape evaluation. 
Kovář P.: Conceptions of landscape-ecological relevance emerged in the Czech botany during the second half of twentieth century

\section{Maps of vegetation}

Let's try to categorize important findings, attitudes and foundations, recognising the importance of the work with landscape in the course of time. The first significant piece of work, filling the gap in the Republic-wide territory understanding, was the map of the original natural vegetation (reconstructed) of the then Czech part of the state Czechoslovakia. The map already existed at the time of the above mentioned paper by the planner J. Štépán who referred to it in his prognosis mentioned above. It was one of the main outputs of the previously mentioned Geobotanical Laboratory of the Academy of Sciences under the leadership of Rudolf Mikyška. It is composed of a series of sheets in the scale of 1:200,000 and a printed key (Mikyška et al., 1969).

The principal concept of the map content is the vegetation that would have covered the area in the existing climate should there be no human influences. The units are - within the phytosociological classification hierarchy - mainly represented by alliances or combined phytosociological units, when it comes to small-scale or heterogenous (and in the given scale difficult to map) assemblages. The map can be used by a non-botanists and serve as one of the analytic basis possible to combine with other mapping characteristics (superposition can result in a synthetic cartogram with mapping contest of higher complexity). At the same time, the depicted vegetation itself can be considered a synthetic characteristic of the enviroment and then an experienced geobotanist is able to deduct various geographical aspects, including climate and soil or, if needed, can form a new interpretation for an ad hoc purpose. It is obvious that both approaches will result in varied complexity, size and structure of the map key.

The map of potential natural vegetation (Neuhäuslová et al., 1998) reconstructs the state of vegetation that would have occured should all human influences cease, i.e. it respects non-reversible changes caused by the civilisation with the exception of those that would cease without ongoing human initiation. This kind of map was published in the scale of 1:500,000 by the Institute of Botany, Academy of Sciences, Czech Republic, thirty years after the previously mentioned first map of the Mikyška's team. It is, thanks to its concept and larger descriptive value regarding the environment, more widely utilizable for planning, respective for the design of territorial systems of ecological stability. The author of the concept is R. Neuhäusl who gradually elaborated it in numerous publications. He says: "mapping of the potential natural vegetation...grows in importance due to its application in landscape ecology and many other practical trends." (Neuhäusl, 1975). The concept has been recognized on the European scale - the map of the potential natural vegetation of Europe was under his editorship, disrupted by his sudden death, published a decade later (Bohn, Neuhäusl, Gollub et al., 2000-2003). It is the result of twenty years long integration work of geographers, ecologists and cartographers from 31 European countries and includes 9 map sheets in the scale of 1:2,500,0000 as well as a general map in the scale of 1:10,000,000. The conceptual approach to the map of the natural vegetation, to which R. Neuhäusl significantly contributed, stresses ecological classification, natural biodiverzity and its anthropogenically caused change, status of conservation and regeneration of natural vegetation, design of the network of protected areas (the latest meeting of stake holders in Vilm 2001 decided on the utilization of the NATURA 2000 concept), comparison between the actual and the potential bio-productivity, ecosystem based management of silvicultures and the impacts of climate change. R. Neuhäusl progressed the furthest in the representation of a whole successful generation of the Czech vegetation ecologists and completed their work on European scale (not to mention he was also an expert in paedogenesis and the relationship between vegetation and soils, an expert in some vegetation types, e.g. peat bog and the author of numerous detailed regional studies of vegetation). His conceptual work, particularly from the 
beginning of the nineties (Neuhäusl, 1991), obtained citing response in international literature, for example in Climate Research, Folia Geobotanica et Phytotaxonomica, Forstwissenschaftliche Centralblatt, Vegetatio resp. Journal of Vegetation Science or Applied Vegetation Science.

The construction of the vegetational content of the map where there is no actual vegetation requires additional knowledge of the relationships and causes of the bond between vegetation and the ecotope (at the very least substrate, soil, microclimate, position and geomorphology). Paleoecologists J. Kyncl, K. and E. Rybníček, M. Peichlová, V. Jankovská, J. Slavíková and others found essential application during the foundation of such a map. Geobotanical mapping supported the establishment of a strong paleobotanical school particularly in Moravia in the last century.

\section{Phytogeographic regionalization}

The application of a vegetation map (namely Mikyška's Geobotanical map, the original sheets of which are stored in the Botanical Institute in Prühonice, in the scale of 1:75,000) was found useful during the creation of the new phytogeographical structure of the former Czech part of the country for the purpose of the multi-volume publication of Flora of Czech (Socialist) Republic in preparation. The map with a Regional phytogeographical classification, that was considerably different from the old one and was built on a very complex and never previously utilised base, was (in the scale of 1:750,000) appended to the first volume of the Flora of Socialist Republic (Hejný, Slavík et al., 1988). V.Skalický, who together with a team of experts prepared the diagnosis of phytochorions, wrote in the introductory chapter: "The phytogeographical regionalisation highlights the landscape component of vegetation and its keystones - the assemblage of plant species - during the regional specification of landscape elements...every landscape is characterised by a certain complex of ecosystems the edificator of which is the vegetation itself. The vegetation of a particular area is formed not only as a result of physically-geographical elements but also its historic development... (Skalický, 1988). E.Hadač was a strong protagonist of complex understanding and delimitation of territorial classification. He worked, together with a team of young geobotanists, mainly on the area of east Bohemia and basically identified his concept with ELU (elementary landscape units) as typological units of landscape on the approximate level of districts or sub-districts of the phytogeographic structure. This formed a rational bridge and resulted in various research activities under the Institute of Landscape Ecology CSAS (E. Hadač was the director) in numerous model areas as well as on the remaining territory of the Czech Republic (within the federal state of Czecholsovakia) and, at the same time, offered good arguments in case of controversy during the planning process of gianto-manic masterpieces of socialism from the point of view of the natural potential of landscape and its conservation (the concept of Regional phytogeographic classification was prepared in advance of the first volume of the Flora of (Socialist) Republic and, therefore, caught Hadač in the full working deployment in the seventies - see for example Skalický (1975). 
Kovár P.: Conceptions of landscape-ecological relevance emerged in the Czech botany during the second half of twentieth century

\section{STRUCTURES IN LANDSCAPE AND THEIR DYNAMICS}

\section{(EXPLANATORY INTERPRETATIONS)}

This includes the above described patches of vegetatation types, as well as linear elements, with the emphasis on one of their function, the biocorridors. Karel Kopecký studied them for the vast majority of his career on the grounds of the Institute of Botany, CSAS, without actually naming them biocorridors. He is one of the few cited authors in Landscape ecology (Forman et Godron, 1986) [the most recent Forman's book Urban ecology. Science of Cities (2014) cites 14 Czech authors]. In the case of Kopecký, the cited study (Kopecký, 1969a) looks into nitrophilous vegetation edges that in the landscape accompany streams or anthropogenic communications and their species composition closely relates to the transformation of the original vegetation into anthropogenic linear communities enriched with nitrogen. They currently form a supporting element for migration or saturation, alternatively a complete replacement of the original elements by invasive species. There are numerous publications in which Kopecký mapped linear coastal, edge or communication bordering vegetation on various gradients, both, altitudinal or nutritional. He is considered to be one of the most often cited botanist of his era. Responses to his work from the end of the sixties and seventies can be found in the following publications: South African Journal of Botany, Preslia, Journal of Vegetation Science, Phytocoenologia, Biológia or Aquatic Botany.

Due to the fact that the studied nitrophilous linear communities are of a strongly dynamic nature and expansive dominants can form other, more or less related communities, can sometimes take over, their nature often clashes with the traditional European vegetation classification system (this led to omitting the so called atypical phytocoenological sets from evaluation). This lack of system classification led Kopecký to the idea of the creation a new system, allowing to classify all coenological records without challenging the hierarchy of the well-established units of the Zurich-Montpellier school of phytosociology. The new method became known as the deductive method of classification (Kopecký, 1969b) and is used nowadays primarily in the countries with poor and synanthropic vegetation (such as The Netherlands). When it becomes impossible to identify a certain set of records while progressing from the top from higher classification ranks towards the lower ones, classification of the vegetation "stops" on a subordinate hierarchic level. That way vegetation classification is "not allowed" further through the classification system. The method emphasises the syngenetic aspect and, therefore, the basic and derivated communities are distinguished (Kopecký et Hejný, 1978). Citing of the basic publications on this method and its applications to certain vegetation was vast, for example in Nova Hedwigia, Journal of Limnology, Phytocoenologia, Vegetatio, Journal of Vegetation Science, Preslia, Applied Vegetation Science, Biológia, Plant Ecology, Candollea, Folia Geobotanica et Phytotaxonomica, Acta Botanica Neerlandica, Botanica Acta, Review of Palaebotany and Palynology.

Another author, who in his times surprised with work of high citation, was Zdeněk Kropáč who studied weeds in crops respective segetal vegetation and its distribution in landscape in relation to agro-technological methods of crop treatment in the environmental context. His work published in the journal Pedobiologia (Jena) was groundbreaking in terms of methodology, it tested methods of quantification of the seeds of crop weeds in the soil seed bank and, as a result, allowed for the prediction of weed infestation (Kropáč, 1966; 104 journal citations found). Citing responses can be found in the following journals: Weed Research, African Journal of Range \& Forage Science, Journal of Aquatic Plant 
Management, Flora, Texas Journal of Science, Weed Technology, Weed Science, Acta Oecologica-International Journal of Ecology, Aquatic Botany, Journal of Ecology, Biotropica, Australian Journal of Experimental Agriculture, Applied Vegetation Science, Grass and Forage Science, Functional Ecology, Agronomy Journal, Pakistan Journal of Botany, Wetlands, Journal of Range Management, Acta Botanica Neerlandica, Agriculture Ecosystems \& Environment, Researches on Population Ecology, Nordic Journal of Botany, Applied Soil Ecology, Progress in Physical Geography, Oecologia, Canadian Journal of Botany etc.

A more general model of agrosystem dynamics with regards to the interaction system between the spring/winter crop and the weed component, with regards to the soil properties (the status of nutrients) and with regards to agro-technological period, was published by Z. Kropáč with co-authors E. Hadač and S. Hejný (Kropáč et al., 1971). It represents a coherent concept of so called agro-ecophases, agro-ecostages and agro-ecocycles in hierarchic interconnection from seasonal to annual or multi-annual cycles which increases the predicability in agricultural landscape management. This work refers in some respects to the previous concept of water level dynamics in reservoirs related to wetland vegetation, respective to macrophytes and their communities, written by Hejný $(1957,1960)$. In the concept, certain eco-phases and eco-periods characterize the change of the environment in a certain rhytm, to which the vegetation is bound while the hierarchically superior concept of ecocycle as a range of hydrological minimums and maximums determines vegetation on community level. The basic ecophases include hydrophasis, litoral ecophase, transitional ecophase, and terrestrial ecophase, corresponding with relevant life forms of vegetation pleustophytes, hydrophytes and helophytes subdivided into partial adaptive strategies. This set of named relationships makes the rules of pond or river functionality to a large extent comprehesive and their management graspable - they were definitely empirically used already by the designers of the pond systems Jakub Krčín or Štěpánek Netolický (the $15^{\text {th }}$ and $16^{\text {th }}$ century).

\section{DRIVING FORCES AND BIODIVERSITY}

The term, that entered the ecology textbooks and is often related to biodiversity, is disturbation as a pendant to another term: stress. Another interaction between geomorphological and climatic factors was described from the Czech territory and mountain areas by Jan Jeník. His "theory of anemo-orographic systems" (Jeník, 1961) successfully explained the exceptionally high geobiodiversity in the kettleholes of the Sudeten Mountains, which was unsucessfully attempted by the naturalists of the previous generations. They referred to the maximum altitude (within the central range), favourable position of slopes towards sunlight or shade or isolated outcrops of rocks suitable for soil formation. With respect to the location of the centres of biodiversity in long-term lee side of mountain ridges, it is possible to distinguish three aerodynamically significant parts: 1. leading windward valleys where wind streams unite (here western winds); 2 . speeding top part where the winds reach high speeds; 3 . turbulent lee side space where the speed of winds decreases and the wind streams become turbulent resulting in sedimentation of debris carried by them. These three consecutive parts can be considered to be an anemo-orographic system. Within this system, the lee side spaces are protected from wind erosion and destruction caused by wind; however, all exogeodynamic processes are basically activated by snowdrifts and, at the time of considerable temperature drop, also by glaciers. The melting of snow-drifts influences hydrological and paedogenetical processes. Various interactions between physical and biological factors lead to various spacial and species composition in the individual parts of 
Kovár P.: Conceptions of landscape-ecological relevance emerged in the Czech botany during the second half of twentieth century

the anemo-orographic system. The mosaic of woodland or tundra species in the deflation top part is more monotonous, while on the lee side there is an opportunity for the co-existence of large amount of communities and species. Frequent avalanche routes create opportunities for germination and growth of heliophilous population of wildlife (due to the influence of an external factor in the community of tufty vegetation and shading woody plants). The accumulation of genetic information on the lee side the anemo-orographic system is supported by its role as a „wasteplain“ of seeds, sporas, fruits and embryos, that are brought by the wind from long distances. In the environment disturbed by avalanches, erosion and gravitational processes forms the perfect opportunity for germination and successful survival of even small populations of various origins. Part of the vegetation in lee side biocentres is a relict from the post-glacial period, whilst another part is a relict from the time of climatic optimum and further part is a result of the current changes caused by anthropogenic processes. In summary, the models of anemo-orographic systems in mountain landscapes explain on the geographical scale the important role of the relief and mesoclimate with associated interactions of biological processes and enable a reconstruction of past processes in the landscape as well as a prediction of the future ones.

Jeník's theory was originally not published in English, which happened much later in a concentrated form, and the lack of availability meant less response on the international scale, despite the fact that the author published the applications of the method in the context of other European mountain ranges, for example Schwarzwald or Vogézy; nevertheless, the synthetically tuned essence of the theory (Jeník, 1990) was cited in publications such as Biochemical Systematics and Ecology, Biológia or Arctic and Alpine Research according to the Web of Science.

Much more cited are Jeník's co-authored publications of data obtained outside of Europe also reaching the landscape level of nature organisation. This is primarily the essay on the tension dynamics between woodland and savannah in Africa (Longman et Jeník, 1992). Citing responses can be found in journals such as Journal of Evolutionary Biology, Earth Interactions, Journal of Biogeography, Annual Review of Ecology and Systematics, Genetica, Evolution, Journal of Ecology, Functional Ecology, Journal of Bryology, Perspectives in Plant Ecology Evolution and Systematics, Flora, Water Resources Research, Global Change Biology, PLOS One, Acta Botanica Brasilica, Journal of Geophysical Research-Biogeosciences, Biological Journal of the Linnean Society.

\section{Landscape-ecological phenomena}

A complex of extraordinary botanical and ecological occurrences formed in borderline environment is in the literature called "a phenomenon"; for example the hilltop/mountaintop phenomenon is caused by the unusual effects of the environment on the tops of hills and mountains; the dolomite phenomenon is caused by the chemistry of dolomite mountains; the karst phenomenon is influenced by the qualities of limestone rocks and layers; the serpentinite effect is caused by the chemistry of the formations composed of serpentinite; the river phenomenon or the valley phenomenon is caused mainly by the erosssive activity of streams in deep valleys; the scree phenomenon is based on the combination of the properties of the parent rock with the dynamics of cavities during the interaction with through-flowing, mostly cold air and leaf mould accumulation or nitrogen accumulation. The representation of various phenomena prints the chararcteristic intergrity into the landscape and displays in the composition of flora and fauna. Numerous causalities contributing to the origins and endurance of landscape phenomena were discovered by the members of the team of these scientists: J. Jeník, J. Slavíková, J. Kubíková, J. Kosinová-Kučerová (mountaintop phenomenon, karst phenomenon, river phenomenon and others). Detailed microclimatic, 
paedological, eco-physiological and production-ecological measurements on the hill Oblík in České Středohoří-Mts. showed that the highest numbers of species and the maximal level of the species diversity index is in the mid-section of the leading gradients of the environment (Slavíková et al,. 1968). The index of dominance, showing a high proven negative correlation with diversity, was reaching the lowest levels under those conditions.

Hadač's publication from the Dolina siedmi prameňov-valley in Slovakia (Hadač et al., 1969), on which he cooperated for example with Moravian born J. Šmarda and many others, can also be considered to be one of this type of works (dolomite phenomenon, inversional occurrence of species and communities - such as de-alpine ones, etc.)

V. Ložek with his colleagues brought an extensive knowledge on the phenomenon of the Quaternary refugia of wildlife, on unitary or linear migrations, on scree phenomenon and others. Brno born geobotanist J. Vicherek introduced original findings about the phenomenon of salt bases and halophilous vegetation. His essay on coenologic-phytogeographical relationships of native vegetation of sandy dunes and salty soils in the eastern Pannonian area is unique (Vicherek, 1973).

\section{ECOPHYSIOLOGY OF DOMINANT ELEMENTS AND THE PRODUCTIVITY OF ECOSYSTEMS}

A group of South-Moravian and also South-Bohemian botanists under the leadership of M. Rychnovská brought, within the then International Biological Programme (stimulated by ICSU/IUBS), a large amount of data on the production abilities and ecophysiological functions of wetland and grassland vegetation (e.g., Rychnovská, 1993). The results were in synthetic works also interpreted in balance studies on the landscape level (Třeboň Basins, areas of Kameničky in the Bohemian-Moravian Highlands, e.g., Rychnovská, 1979). Here are at least some of the names represented in the research teams in the sixties and the seventies: E. Balátová-Tuláčková, B. Úlehlová, J. Gloser, M. Tesařová, V. Zelená, K. Fiala, J. Jakrlová, J. Květ, and others. Published monographic editions of summarising projects from IBP and associated MAB understandably did not receive as many citations in index journals as papers published in confessional publications - in this comparison ecophysiologists (J. Květ, J. Gloser, and other) fare the best with tens of citing responses.

\section{SUCCESSION OF VEGETATION AND ECOLOGICAL RESTORATION}

Listing those Czech researchers that were forced to emmigrate is problematic because the conditions and stimuli for research and publication were different in the free world. No direct comparison is; therefore, possible. J. Fanta used to live in the Netherlands and worked in academic, or university field (Amsterdam, Wageningen). His own and co-edited works brougth original findings about secondary post-Holocene succession of woody vegetation on sand dunes forming an Eolitic overlay in periglacial area threatened by the raising sea leavels during the climate change (Fanta et Siepel, 2010).

There were many responses to the selected study of mountainous woodland formations in the Czech Republic (Emmer, Fanta, Kobus et al., 1998) in journals such as Forest Ecology and Management, European Journal of Forest Research, Ecosphere, Ornis Fennica, Scientific World Journal, Forest Systems, Scandinavian Journal of Forest Research. 
Kovář P.: Conceptions of landscape-ecological relevance emerged in the Czech botany during the second half of twentieth century

\section{VEGETATION INVASIONS AND LANDSCAPE MANAGEMENT}

Marcel Rejmánek belongs to the "youngest generation of the oldest". He emmigrated at the beginning of the eighties to the U.S. where he still works at California University in Davis. He established himself on the scene mainly through invasive ecology and a large number of his publications, often on the global scale, enjoy higher citing response when it comes to the topic than it used to be common for his predecessors. His engagement is wide and he (together with other co-authors) considerable contributed to the understanding of invasiveness of plants, invasibility of communities, to species specific surveys, often on the level of the whole families with calculations of the invasive ability of seedlings (mainly in conifers, e.g. Pinaceae). Number of his publication is built on experimental research of long-term monitored study areas, amongst others also in the tropics (Belize, north of South America). He tests the invasion success of relevant predatory species under various methods of applied management and the impact on the landscape scale is obvious. Examples of publications and citing responses:

A theory of seed plant invasiveness: The first sketch

By: Rejmanek, $M$

BIOLOGICAL CONSERVATION Volume: 78 Issue: 1-2 Pages:

171-181 Published: OCT-NOV 1996

Number of responses: 262

Invasive plants: approaches and predictions

By: Rejmanek, M

Conference: 1st Joint Conference of the

Ecological-Society-of-Australia/New-Zealand-Ecological-Society Location: DUNEDIN, NEW ZEALAND Date: 1998

Sponsor(s): Ecol Soc Australia; New Zealand Ecol Soc

AUSTRAL ECOLOGY Volume: 25 Issue: 5 Pages: 497-506 Published: OCT 2000

Number of responses: 268

Alien plants in checklists and floras: towards better communication between taxonomists and ecologists By: Pysek, P; Richardson, DM; Rejmanek, M; et al. TAXON Volume: 53 Issue: 1 Pages: 131-143 Published: FEB 2004

\section{Number of responses: 409}

In the case of M.Rejmánek it is great that the complete circle of the overview of the botanists can be drawn through the connection with E. Hadač to whom is the set of these published contributions dedicated to celebrate the anniversary of his birthday. Rejmánek considers himself to be his follower and they published a paper together at Hadač's old age in the journal Oikos: Safford, Rejmánek et Hadač (2001): Species pools and the "hump-back" model of plant species diversity: an empirical analysis at a relevant spatial scale. 


\section{REFERENCES}

Bohn, U., Neuhäusl, R., Gollub, G., Hettwer, C., Neuhäuslová, Z., Schlüter, H. \& Weber, H. (eds.) (2000-2003). Karte der natürlichen Vegetation Europas. Maßstab $1: 2500$ 000. Teil 1-3. Landwirtschaftsverlag, Münster.

Emmer, I.M., Fanta, J., Kobus, A.T. et al., (1998). Reversing borealization as a means to restore biodiversity in Central-European mountain forests - an example from the Krkonose Mountains, Czech Republic. Biodiversity and Conservation, 7(2): 229-247.

Fanta, J., Siepel, H. (eds)(2010). Inland drift sand landscapes. - KNNV Publishing, Zeist, The Netherlands.

Forman, R.T.T. (2014). Urban ecology. Science of cities. Cambridge University Press, New York.

Forman, R.T.T., Godron, M. (1986). Landscape ecology. - John Wiley \& Sons.

Hadač, E. et al. (1969). Die Pflanzengesellschaften des Tale "Dolina Siedmich prameňov" in der Belaer Tatra. Vydavatel'stvo Slovenskej akadémie vied, Bratislava.

Hejný, S. (1957). Ein Beitrag zur ökologischen Gliederung der Makrophyten der tschechoslowakischen Niederung sgewässer. Preslia, 29: 349-368.

Hejný, S. (1960). Ökologische charakteristik der Wasser- und Sumpfplanzen in den Slowakischen Tiefebenen (Donau- und Theissgebiet). Vydavatelstvo SAV, Bratislava.

Hejný, S., Slavík, B., (eds.)(1988). Květena ČSR I. Academia, Praha.

Jeník, J., (1961). Alpinská vegetace Krkonoš, Králického Sněžníku a Hrubého Jeseníku: teorie anemo-orografických systémů. Nakladatelství ČSAV, Praha.

Jeník, J., (1990). Large-scale pattern of biodiversity in Hercynian massifs. In: Krahulec F., Agnew S. et al. (eds.)(1990): Spatial processes in plant communities (p. 252-259). The Hague.

Klika, J., (1948). Plánujeme s př́rodou. - Brázda, Praha.

Kopecký, K., (1969a). Zur Syntaxonomie der naturlichen nitrophilen Saumgesellschaften in der Tschechoslowakei und zur Gliederung der Klasse Galio-Urticetea. Folia Geobot. Phytotax., 4: 235-259.

Kopecký, K., (1969b). A proposal of classification of vegetation habitats on banks of Czechoslovak water courses from hydrological standpoint. Archiv für Hydrobiologie, 66(3): 326.

Kopecký, K. et Hejný, S., (1978). Use of a so-called deductive method in syn-taxonomic classification of roadside plant communities in NE Bohemia. Vegetatio, 36(1): 43-51.

Kropáč, Z., (1966), Estimation of weed seeds in arable soils. Pedobiologia, 6: 105-128.

Kropáč, Z., Hadač, E. et Hejný, S. (1971). Some remarks on the synecological and syntaxonomic problems of weed plant communities. Preslia, 43: 139-153.

Longman, K.A. et Jeník, J., (1992). Forest-savanna boundaries - general considerations. - In: Furley, P.A., Proctor, J. et Ratter, J.A. (eds.)(1992): Nature and dynamics of forest-savanna boundaries (p. 3-20). Chapman \& Hall, London.

Mikyška, R., (1948). Nástin hlavních zásad pro biologické plánování. In: Klika J., Plánujeme s prírodou, Brázda, Praha.

Mikyška, R., [red.] et al. (1969). Geobotanická mapa ČSSR. 1. České země. Academia, Praha. 
Kovár P.: Conceptions of landscape-ecological relevance emerged in the Czech botany during the second half of twentieth century

Neuhäusl, R., (1975). Kartierung der potentiell naturlichen Vegetation in der Kulturlandschaft. Preslia, 47: 117-128.

Neuhäusl, R., (1991). Vegetation map of Europe - 1st results and current state. Journal of Vegetation Science, 2(1): 131-134.

Neuhäuslová, Z., et al. (1998). Mapa potenciální přirozené vegetace České republiky. Praha, AV ČR, Botanický ústav.

Rychnovská, M., (ed.)(1979). The function of grasslands in a spring region - the Kameničky project. Progress Report on MAB Project No. 91, Brno.

Rychnovská, M., (ed.)(1993). Structure and functioning of seminatural meadows. - Elsevier, Amsterdam.

Safford, H.D., Rejmánek, M. et Hadač, E., (2001). Species pools and the "hump-bach" model of plant species diversity: an empirical analysis at a relevant spatial scale. Oikos, 95: 282-290.

Skalický, V., (1975). Die regional-phytogeographische Gliederung des Westböhmischen Bezirkes. Folia Mus. Rer. Natur. Bohem. Occid. - Bot., Plzeň, 6: 1-39.

Skalický, V., (1988). Regionálně fytogeografické členění (Regional phytogeographical division). - In: Hejný S., Slavík B. (eds): Květena České socialistické republiky (pp. 103-121, Flora of the Czech Republic) 1. Academia, Praha.

Slavíková, J. et al. (1968). Ecological and vegetational differentiation of the solitary conic hill. Vegetace ČSSR, Ser. A, Academia, Praha.

Štěpán, J., (1976). Prognóza krajinoekologických podmínek fytogeografických okresů v ČSR. Preslia, 48: 163-184.

Úlehla, V., (1947). Napojme prameny. Život a práce, Praha.

Vicherek, J., (1973). Die Pflanzengesellschaften der Halophyten- und Subhalophytevegetation der Tschechoslowakei. Vegetace ČSSR, Ser. A, Academia, Praha. 